\title{
Do N-Methyl-D-Aspartate Receptors Mediate Synaptic Responses in the Mudpuppy Retina?
}

\author{
Paul A. Coleman and Robert F. Miller \\ Department of Ophthalmology, Washington University School of Medicine, St. Louis, Missouri 63110
}

\begin{abstract}
Whole-cell recordings of amacrine and ganglion cells in the supertused retina-eyecup preparation of the mudpuppy were obtained in order to determine which excitatory amino acid receptor (EAAR) subtype mediates the synaptic responses of these neurons. All third-order retinal neurons tested were depolarized by kainic acid (KA), $\boldsymbol{N}$-methyl-D-aspartate (NMDA), and quisqualate (QQ). The responses evoked by NMDA were blocked by the addition of 0-2-amino-5-phosphonovaleric acid (D-AP5) and D-2-amino-7 phosphonoheptonoic acid (D-AP7) to the perfusate. When the actions of exogenously applied NMDA were completely blocked by D-AP5 and D-AP7, the light-evoked responses of inner retinal neurons persisted without any apparent reduction or, alternatively, a slight enhancement of the response was observed. Light-evoked responses of bipolar, amacrine, and ganglion cells associated with the On pathway were attenuated by L-AP5 in a manner similar to its lower-order homolog L-2-amino-4-phosphonobutyrate (AP4); nevertheless, L-AP5 was not an effective NMDA antagonist. Although synaptic transmission between retinal second- and third-order neurons appears to be mediated by EAARs, the NMDA receptor does not appear to play a prominent role under our experimental conditions. Nevertheless, our results suggest that the racemic mixture of AP5 should not be used as an NMDA antagonist in retinal research, due to the AP4-like actions of its L-enantiomer.
\end{abstract}

The "glutamate" hypothesis of excitatory neurotransmission in the retina has become widely accepted. It seems likely that photoreceptors and bipolar cells release glutamate, aspartate, or a closely related analog that activate second- and third-order neurons. Advancements in this field have come about by the introduction of compounds having selective actions on subpopulations of retinal neurons (Miller and Slaughter, 1986). An interesting group of compounds, the $\alpha$-amino- $\omega$-phosphonocarboxcylic acids, differentially effects retinal excitatory amino acid receptors (EAARs) depending on the stereospecificity and the number of carbon atoms in the molecule. For example, $L(+)-$ 2-amino-4-phosphonobutyrate (AP4) acts as an agonist for the EAAR of the depolarizing bipolar cell (Slaughter and Miller, 1981), whereas the $D(-)$-enantiomer of a higher-order homolog 2-amino-7-heptonoate (AP7) is a potent and specific antagonist

\footnotetext{
Reccivcd Jan. 7, 1988; rcvised Mar. 29, 1988; accepted Apr. 4, 1988.

Supported by NEI Grant EY 03014.

Correspondence should be addressed to Paul A. Coleman, Department of Physiology, University of Minnesota, 6-255 Millard Hall, 435 Delaware Street S.E., Minneapolis, MN 55455.

Copyright (C) 1988 Society for Neuroscience $0270-6474 / 88 / 124728-06 \$ 02.00 / 0$
}

of the $N$-methyl-D-aspartate (NMDA) receptor (Massey and Miller, 1985). The actions of these drugs appear sufficiently restricted such that little pharmacological overlap between the two has been observed.

DL-2-Amino-5-phosphonovalerate (AP5) also has network selective effects. Like AP4, DL-AP5 also attenuates the photic response of retinal neurons associated with the On system (Ikeda and Sheardown, 1983; Bolz et al., 1984; Slaughter and Miller, 1985). Because the racemic mixture of AP5 is also a potent NMDA antagonist, it was suggested that sustained On responses of third-order neurons were mediated by NMDA receptors ( $\mathrm{Lu}-$ kasiewicz and McReynolds, 1985). This conclusion conflicted with an earlier report by Slaughter and Miller (1983), who used $\mathrm{D}-\alpha$-amino adipate and $\mathrm{D}-\alpha$-amino suberate to block NMDA receptors; these NMDA antagonists did not affect the lightevoked responses of third-order neurons, except for a particular subclass of Off ganglion cells. To better understand the role of NMDA receptors in light-activated synaptic transmission, we have used the separate enantiomers of AP5 and AP7 on secondand third-order neurons. We report that the D-form of AP5 and AP7 blocked NMDA receptors but did not block synaptic responses associated with the On system. However, L-AP5 was a poor NMDA antagonist and had effects similar to the L-AP4 suppression of the On bipolar cell described by Slaughter and Miller (1981). Thus, our findings indicate that NMDA receptors do not mediate the major components of the synaptic responses of third-order retinal neurons. The initial results of these experiments have appeared in abstract form (Coleman and Miller, 1987).

\section{Materials and Methods}

The superfused retina-eyecup of the mudpuppy, Necturus maculosus (Miller and Dacheux, 1976), was used for the present experiments. After the animals were decapitated and pithed, the head was hemisected and placed on a Ringer's soaked cotton ball. The anterior chamber of the eye was opened permitting the iris, lens, and the vitreous humor to bc removed. This preparation was then placed into a light-tight Faraday cage.

The gravity-feed perfusion system consisted of eleven syringes (10 $\mathrm{ml}$ ) connected, with plastic valves, to a common manifold. The perfusate exited the manifold by 24-gauge Teflon tubing and flowed into the eyecup through a pipette placed at the edge of the retina. The perfusate consisted of a modified Ringer's solution containing $111 \mathrm{mM} \mathrm{NaCl}, 2.5$ $\mathrm{mM} \mathrm{KCl}, 1.8 \mathrm{~mm} \mathrm{CaCl}, 1 \mathrm{~mm} \mathrm{MgCl}$, $5 \mathrm{~mm}$ dextrose, $10 \mathrm{~mm}$ HEPES, and titrated to $\mathrm{pH} 7.80$ with $\mathrm{NaOH}$. All pharmacological agents were added to the control perfusate and the $\mathrm{pH}$ adjusted, if necessary. The perfusate was bubbled with $100 \%$ oxygen and flowed at a rate of $1-2$ $\mathrm{ml} / \mathrm{min}$. This system had an exchange time between different solutions of approximately 20-30 sec, due to dead space in the lines.

Physiological data were obtained from individual neurons $(n=40)$ using either conventional intracellular recordings or the whole-cell recording (WCR) technique we recently developed for use in the intact 


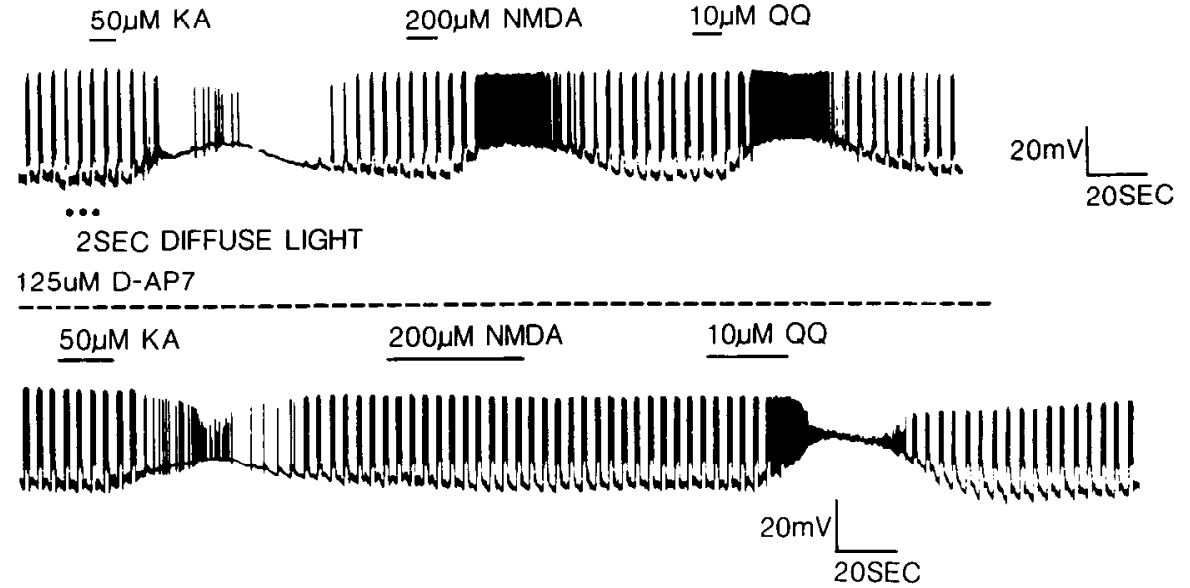

Figure 1. WCR from an On sustained ganglion cell in the mudpuppy retina. Application of each of the EAAR agonists is indicated by the vertical solid line above the voltage record, whereas the antagonist is indicated by the dashed line. This cell was depolarized by $\mathrm{KA}$ (50 $\mu \mathrm{M})$, NMDA (200 $\mu \mathrm{M})$, and QQ (10 $\mu \mathrm{M})$. D-AP7 $(125 \mu \mathrm{M})$ only blocked the effects of NMDA. However, the lightevoked response persisted in the presence of the NMDA antagonist. retina (P. A. Coleman and R. F. Miller, unpublished observations). The WCR electrodes were made with thin-wall borosilicate, Omega-dot glass tubing (O.D. $=1.2 \mathrm{~mm}, \mathrm{I} . \mathrm{D} .=0.86 \mathrm{~mm}$; Glass Company of America) and had tips that were 1-2 $\mu \mathrm{m}$ in diameter and were 8-12 $\mathrm{M} \Omega$ in resistance when filled with the intracellular clectrolyte solution. This solution consisted of $\mathrm{KCH}_{3} \mathrm{SO}_{4}, 90 \mathrm{mM} ; \mathrm{NaCH}_{3} \mathrm{SO}_{4}, 5 \mathrm{~mm} ; \mathrm{MgSO}_{4}, 10$ mм; $\mathrm{CaCl}_{2}, 1 \mathrm{~mm}$; EGTA, $11 \mathrm{~mm}$; HEPES, $5 \mathrm{~mm}$; glucose, $2 \mathrm{~mm}$; glutathione, $1 \mathrm{~mm}$; ATP- $\mathrm{Mg}^{2+}, 1 \mathrm{~mm}$; phenol red, $0.0004 \%$. The solution was titrated to a $\mathrm{pH}$ of 7.2 with $\mathrm{KOH}$, which brought the final $\mathrm{K}^{+}$ concentration to approximately $125 \mathrm{~mm}$.

Conventional intracellular electrodes were made using medium-walled Omega-dot glass tubing (O.D. $=1.2 \mathrm{~mm}$, I.D. $=0.6 \mathrm{~mm}$; Glass Company of America) and fabricated on an ultrafine micropipette puller (Campden Instruments). When filled with $1.5 \mathrm{M} \mathrm{KC}_{2} \mathrm{H}_{3} \mathrm{O}_{2}$, the electrode resistance was 150-200 M . The intracellular potentials were monitored with a Dagan 8100-1 amplifier. Conventional intracellular records were obtained in order to confirm that no artifacts were introduced by the WCR technique. Identical pharmacological results were acquired using either technique. ERG clectrodes were made as conventional intracellular electrodes, with the tips broken back and beveled until they were approximately $5 \mathrm{M} \Omega$ when filled with Ringer's solution. The D.C. recordings of the ERG were monitored using a Grass P-16 amplifier.

A dual-beam light bench projected focused images of a spot $(100$ $500 \mu \mathrm{m})$, a slit $(130 \mu \mathrm{m} \times 10 \mathrm{~mm})$ or diffuse light onto the retina (irradiance $=1-2 \mathrm{~mW} / \mathrm{m}^{2}$ ). The light pulses were $2 \mathrm{sec}$ in duration and controlled with electromechanical shutters (Uniblitz, Vincent Associates). Intensity was controlled using two counterbalanced neutral density wedges (Kodak).

\section{Results}

Figure 1 shows that bath application of the three EAAR agonists $\mathrm{KA}(50 \mu \mathrm{M}), \mathrm{NMDA}(200 \mu \mathrm{M})$, and QQ $(10 \mu \mathrm{M})$ to an On ganglion cell resulted in a depolarizing response, accompanied by action potentials. These drugs activate EAARs intrinsic to third-order neurons (Slaughter and Miller, 1983; Lukasiewicz and McReynolds, 1985; Coleman et al., 1986). The perfusate bathing the retina was switched to one containing $125 \mu \mathrm{M}$ of the D-enantiomer of AP7 and the agonists reapplied. Both KA and QQ depolarized the cell but NMDA was ineffective. This indicated that D-AP7 was a selective NMDA antagonist for mudpuppy inner retinal neurons.

Although D-AP7 successfully blocked the depolarizing effects of bath applied NMDA, Figure 1 also shows that the lightevoked response of the neuron persisted. For other cells DLAP7 was used; which also was a potent NMDA antagonist but also did not block the light-evoked response of any neuron tested. The results with AP7 contrasted sharply with the observations obtained with the NMDA antagonist DL-AP5. Other studies have shown that the light-evoked responses of ganglion cells (especially On cells) were attenuated by DL-AP5 (Ikeda

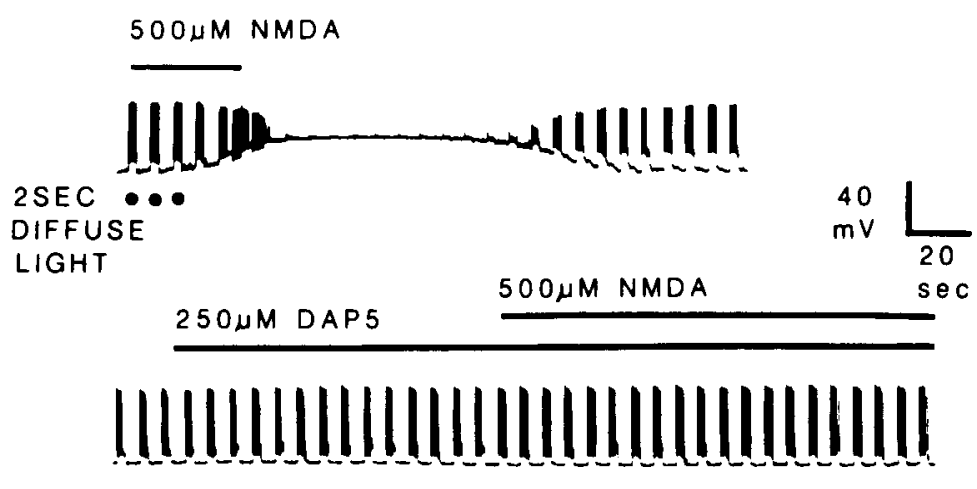

$250 \mu M$ LAP5 $500 \mu \mathrm{M}$ NMDA

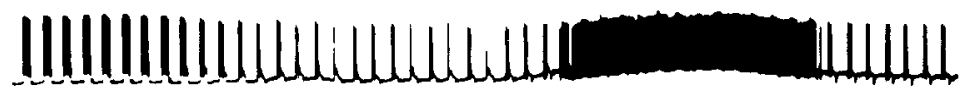

Figure 2. WCR from an On sustained ganglion cell which was depolarized by NMDA $(500 \mu \mathrm{M})$. Application of D-AP5 $(250 \mu \mathrm{M})$ completely blocked the effects of NMDA; nevertheless, no effect on the light-evoked response was observed. In contrast, L-AP5 $(250 \mu \mathrm{M})$ reduced the light-evoked response of this cell but could not block the depolarization and increase in spike activity caused by NMDA. 
Figure 3. WCR from an Off ganglion cell in which the effects of NMDA (500 $\mu \mathrm{M})$ and DHS $(250 \mu \mathrm{M})$ are contrasted. Although the depolarization evoked by $\mathrm{KA}(30 \mu \mathrm{M})$ was unaffected by D-AP7 $(250 \mu \mathrm{M})$, the responses evoked by NMDA and DHS were essentially eliminated.

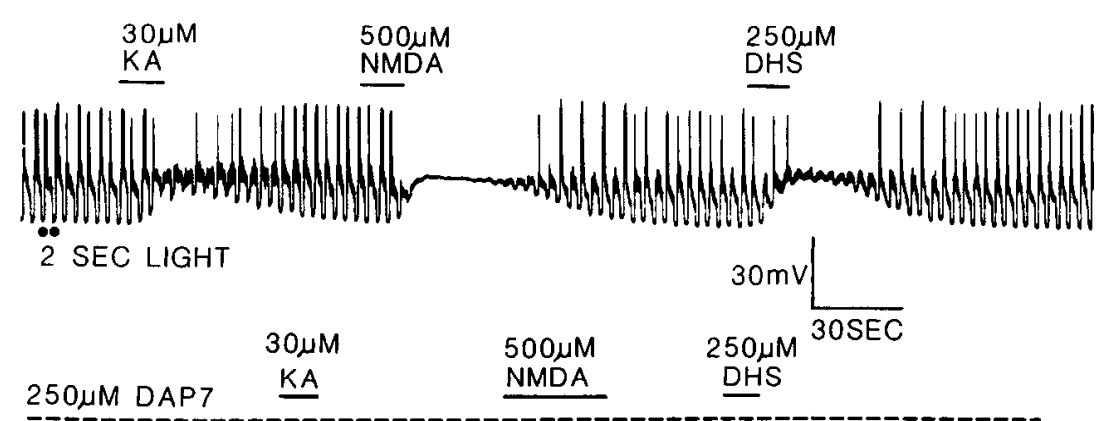

and Sheardown, 1983; Bolz et al., 1984; Lukasiewicz and McReynolds, 1985; Coleman and Miller, 1987). In order to discern the basis for this apparent discrepancy, the separate enantiomers of AP 5 were tested. The sustained On ganglion cell illustrated in Figure 2 was depolarized by NMDA $(500 \mu \mathrm{M})$. The same cell was exposed to D-AP5 $(250 \mu \mathrm{M})$, which blocked
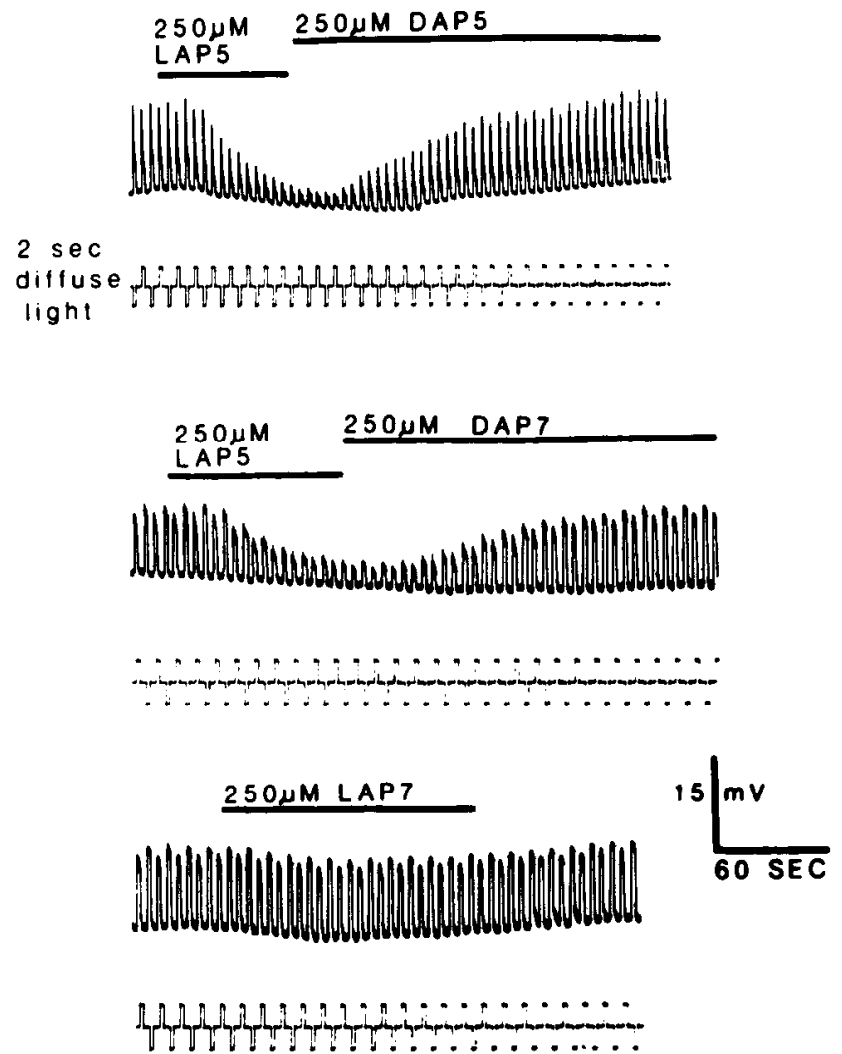

Figure 4. Conventional intracellular recordings from On bipolar cells in which L-AP5 $(250 \mu \mathrm{M})$ was applied. Like its lower-order homolog L-AP4 (Slaughter and Miller, 1981), L-AP5 reduced the amplitude of the photic response of this class of second-order neurons. When the perfusate was changed to one containing an NMDA antagonist (either D-AP5 or D-AP7), the amplitude of the light-evoked response returned to control levels. the depolarizing effects of NMDA. As happened with the higherorder homolog D-AP7, D-AP5 proved to be a potent NMDA antagonist but left the light-evoked response essentially unchanged.

The bottom trace of Figure 2 shows results with the $\mathrm{L}(+)-$ enantiomer of AP5. The light-evoked response from this On ganglion cell was severely attenuated when L-AP5 $(250 \mu \mathrm{M})$ was added to the perfusate. This reduction in the light-evoked response was not accompanied by the blockade of the NMDA receptors since NMDA still evoked a significant depolarization. Though not illustrated here, the effects of L-AP5 were completely reversible. These experiments show that the light-evoked response of On ganglion cells did not significantly dcpcnd upon NMDA receptors.

To further characterize the ganglion cell NMDA receptors, another EAAR agonist, D-homocysteine sulphinic acid (DHS), was tested. In other regions of the brain, DHS appears to be a selective NMDA receptor agonist (Mewett et al., 1983). Figure 3 shows the depolarizing effects of KA (30 $\mu \mathrm{M})$, NMDA (500 $\mu \mathrm{M})$, and DHS (250 $\mu \mathrm{M})$ on an Off ganglion cell. As seen in the lower trace, when these agents were tested against D-AP7 (250 $\mu \mathrm{M}$ ), the effects of DHS were largely blocked in a manner similar to NMDA itself. Nevertheless, careful examination of the bottom trace shows that DHS slightly decreased the amplitude of the light-evoked response in the presence of D-AP7. This indicates that DHS may have some weak agonist effects on nonNMDA receptors. As a comparison, we challenged the effects of another closely related EAAR agonist, D-homocysteic acid (DHC), against the NMDA antagonists. The depolarizing effects of DHC were unaffected by the NMDA antagonists. In accord with previous results (Mewett et al., 1983), DHS was an effective NMDA agonist, whereas the related analog, DHC, activated a broader spectrum of EAARs.

Figure 3 also shows the light-evoked responses of Off ganglion cells, in our sample, were not reduced by NMDA antagonists. In our experience there has been little observed effect on the light-evoked PSPs of the mudpuppy inner retinal neurons during bath application of either D-AP5 or D-AP7; however, under different stimulus conditions the action of NMDA receptors may be more apparent. Nonetheless, since the On responses of inner retinal neurons were attenuated by L-AP5, a poor NMDA antagonist, we concluded that its effects were mediated by a 


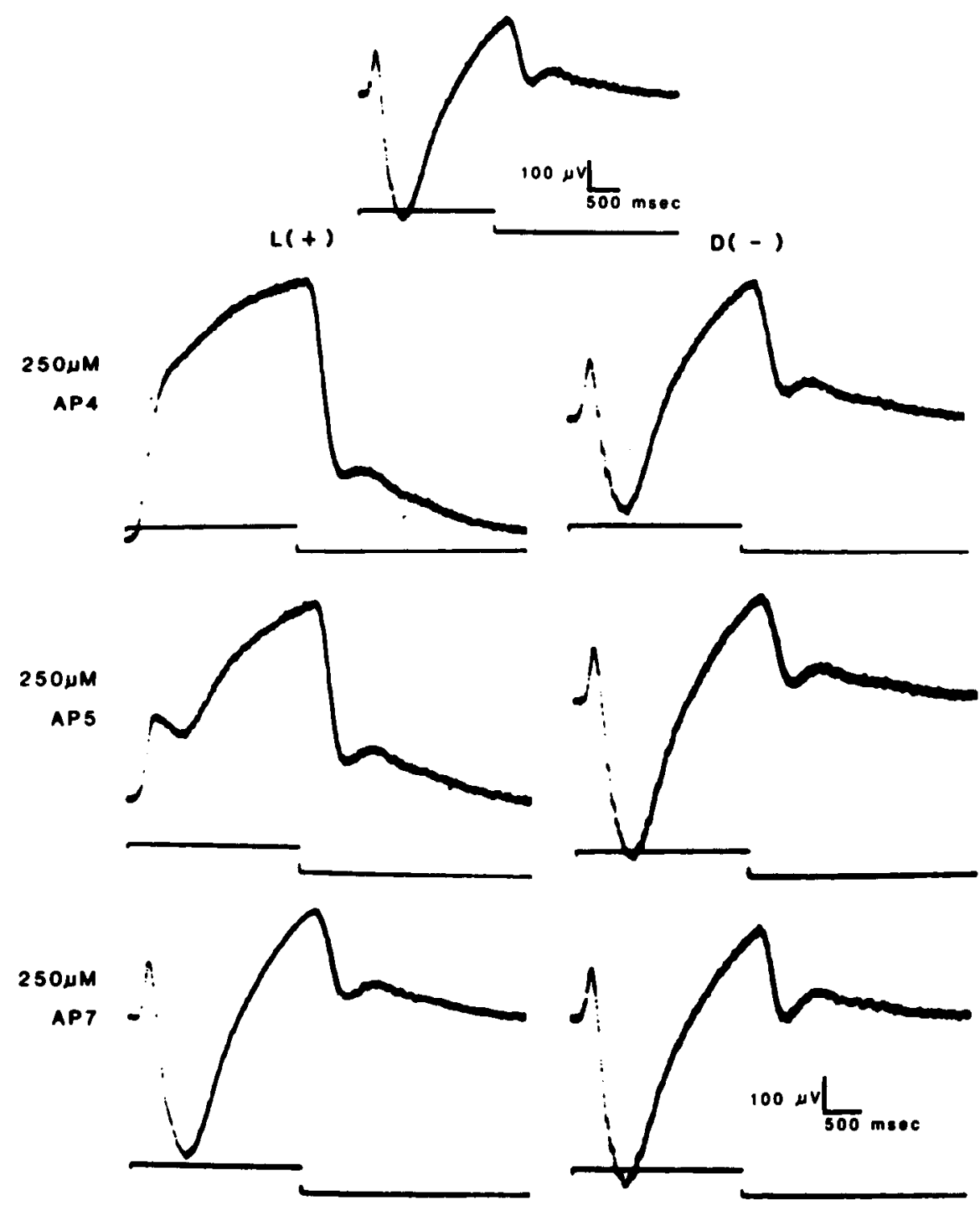

Figure 5. Recordings of the electroretinogram (ERG) during applications of the separate enantiomers of AP4, AP5, and AP7. The b-wave in these records appeared as a large downward deflection due to the intraretinal placement of the ERG electrode below the $b$-wave isopotential point. The b-wave was most effected by L-AP4 and L-AP5. In contrast, the NMDA antagonists D-AP5 and D-AP7 had no obvious effect on any of the components of the ERG.
non-NMDA receptor. It is unlikely that L-AP5 blocks the lightevoked responses of ganglion and amacrine cells by acting as an antagonist to $\mathrm{KA}$ or $\mathrm{QQ}$ receptors, since concentrations of DL-AP5 sufficient to reduce light-evoked activity did not block the depolarizing effects of KA and QQ (Lukasiewicz and Mckeynolds, 1985).

Previous studies have shown that DL-AP5 is an agonist for the On bipolar EAAR (Slaughter and Miller, 1985). This unique receptor is often referred to as the "APB receptor" because of the high affinity with which 2-amino-4-phosphonobutyrate serves as an agonist for the activation of the receptor. It would not be surprising that the L-enantiomer of the one carbon chain longer homolog, AP5, had a similar mode of action. Therefore, since the D-enantiomer did not reduce the light-evoked response of ganglion cells and the L-enantiomer did, we tested the possibility that the effects of L-AP5 were localized to the On bipolar cell.

Intracellular recordings were maintained from On bipolar cells during L-AP5 perfusion. Figure 4 shows that L-AP5 (250 $\mu \mathrm{M})$ reduced the amplitude of the light-evoked response of the On bipolar cells. To further demonstrate that NMDA receptors were not involved in the On bipolar response, the perfusate was switched to one containing either D-AP5 (upper trace) or D-AP7 (middle trace). Regardless of which NMDA antagonist was ap- plied, the amplitude of the On bipolar light-evoked response returned to levels observed in the control perfusate. Application of L-AP7 had essentially no effect on the light-evoked response of On bipolars (bottom trace) or any other inner retinal neuron tested.

The neuronal basis of the b-wave of the electroretinogram (ERG) is the On bipolar cell (Dick and Miller, 1985). Therefore, drugs that reduce the light-evoked response of the On bipolar cell should also reduce the amplitude of the b-wave. In this sense, the ERG is a useful tool because it allows a comparison to be made between many drugs with little concern about the stability of the recording. Figure 5 shows the effects of the Dand L-forms of AP4, AP5, and AP7 $(250 \mu \mathrm{M})$ on the b-wave of the ERG. The b-wave, seen as the large downward transient response, was completely eliminated by application of L-AP4. This effect was stereo specific in that the b-wave was only partially attenuated with an equal concentration of the D-enantiomer. Application of L-AP5 also caused a large reduction in the b-wave, leaving only a small remnant of the response, whereas L-AP7 had little if any effect on b-wave amplitude. Both the D-enantiomers of AP5 and AP7 had virtually no effect on the b-wave or any other component of the ERG. Since the ERG largely reflects the activity of the outer retina, this result indi- 
ON BIPOLAR

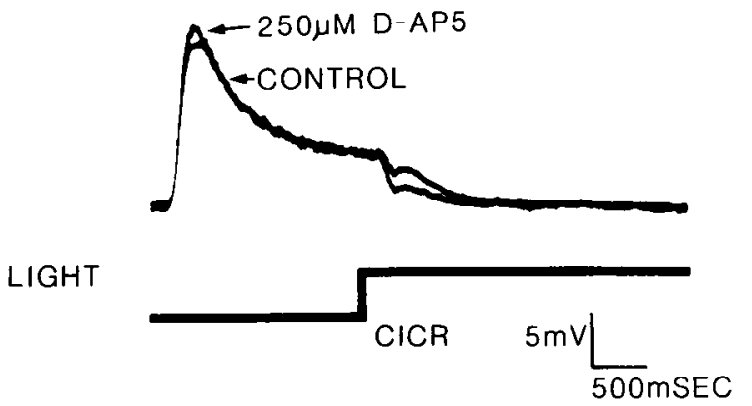

OFF GANGLION CELL

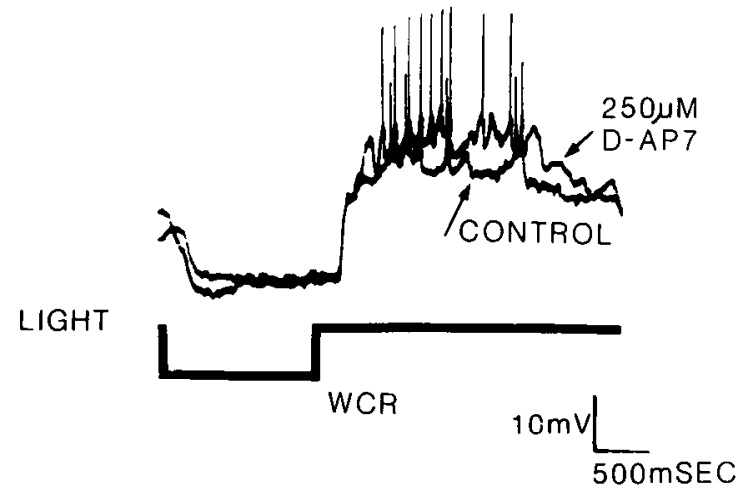

Figure 6. Superimposed records from an On bipolar cell and an Off ganglion cell before and after application of D-AP5 and D-AP7. As shown here, if these NMDA antagonists had an effect on synaptically evoked responses, a slight enhancement was observed.

cated that NMDA receptors exerted no measurable influence upon signal transmission between photoreceptors and secondorder neurons. These results, using the ERG, mirrored our intracellular On bipolar cell data using L-AP5 and the NMDA antagonists. In addition, there is little evidence suggesting the presence of NMDA receptors among the neurons of the outer retina; application of NMDA, even in high concentrations, had little influence on photoreceptors, horizontal, and bipolar cells (Slaughter and Miller, 1983; Massey and Miller, 1987).

Although the NMDA receptor antagonists do not reduce the light-evoked response of retinal neurons, on occasion they have been observed to slightly increase the light-evoked PSPs. Figure 6 (top) shows 2 superimposed responses from the On bipolar illustrated in Figure 4. If D-AP5 was observed to have any effect, it slightly increased the PSPs of these neurons. The same effect was observed for D-AP7 on other bipolar cells. A similar enhancement was also seen in some third-order neurons, as illustrated with the Off ganglion cell illustrated at the bottom of Figure 6. In the presence of D-AP7, the light-evoked response from this Off ganglion cell was slightly enhanced. A slight enhancement was also observed on occasion in some On ganglion cells also (not shown).

One possible reason for larger PSPs in some neurons could have been that NMDA antagonists increased the input resistance $\left(R_{n}\right)$ of these cells. Figure 7 shows the $I-V$ relationship of the Off ganglion cell presented in the previous figure, evaluated in the absence or presence of D-AP7. The $R_{n}$ was fit to the data using a least-squares approximation of the linear regression. When measured in the dark, there was a slight increase ( $27 \mathrm{M} \Omega$ ) in the input resistance of this cell with the NMDA antagonist. But considering the small relative change in $R_{n}(<3 \%)$ and that only half of the cells tested in this manner $(n=4)$ showed an increased $R_{n}$ with the application of the NMDA antagonists, it seems likely that additional mechanisms may be involved in the enhancement phenomena. A similar observation was recently reported (Forsythe and Westbrook, 1988) that nonNMDA, EAAR-mediated synaptic EPSPs between cultured hippocampal neurons were also enhanced after the blockage of NMDA receptors.

\section{Discussion}

Virtually all third-order neurons of the mudpuppy retina respond to KA, NMDA, and QQ. Evidence presented elsewhere suggests that these agonists activate separate receptors (Coleman et al., 1986). Determining the functional role of the individual EAARs is almost impossible without the use of selective antagonists since retinal amacrine and ganglion cells are all depolarized by each of these EAAR agonists. Certainly the NMDA receptor antagonists are the most selective, and in other regions of the CNS, NMDA antagonists have been useful in establishing the functional role of this class of EAAR (Salt, 1986).

In this paper, we have demonstrated that only the D-enantiomer of AP5 worked as an effective NMDA antagonist, while the L-form exhibited very little antagonism to exogenously applied NMDA. Similar results were also obtained with AP7. Yet, when we examined the suppressive effects of AP5 on the lightevoked responses of ganglion cells, we observed the reverse sensitivity. Relatively high levels of D-AP5, which completely eliminated responses to exogenous NMDA, did not block the light response of On cells, whereas the L-enantiomer did. Thus, we conclude that the DL-AP5-mediated reduction in the On responses of ganglion cells previously reported (Ikeda and Sheardown, 1983; Bolz et al., 1984; Lukasiewicz and McReynolds, 1985) was not due to a block of NMDA receptors but to the non-NMDA action of the L-enantiomer of the racemic mixture used.

Analysis of On bipolars shows that L-AP5 blocked On bipolar cell light responses and can therefore account for the suppression of On responses of ganglion cells when the racemic mixture of AP5 was employed. The effects of L-AP5 are similar to those of L-AP4, which has proven to be a highly selective agonist for the On bipolar synaptic receptors (Slaughter and Miller, 1981). It is interesting to note that L-AP7, two carbons longer than AP5, had essentially no effect as an agonist for the synaptic On bipolar EAAR. Thus, the racemic mixture of AP7 could be used as an NMDA antagonist, whereas the racemic mixture of AP5 is contraindicated as an NMDA antagonist because of the "AP4like" actions of the L-enantiomer.

It is quite perplexing that no major portion of the light-evoked responses was blocked with the NMDA antagonists simply because of the ubiquitous nature of these receptors among inner retinal neurons. Similar results have been found in this laboratory on the rabbit retina, in that there was no alteration in the receptive field properties of the ganglion cells tested (S. C. Massey and R. F. Miller, personal communication). However, in contrast to the present results, a small reduction in the number of light-evoked action potentials was observed in many ganglion cells using AP7 as an antagonist. The significance of this discrepancy is not clear, but it does not undermine the major agreement between these and earlier studies (Slaughter and Miller, 1983) that NMDA receptors do not subserve the major 

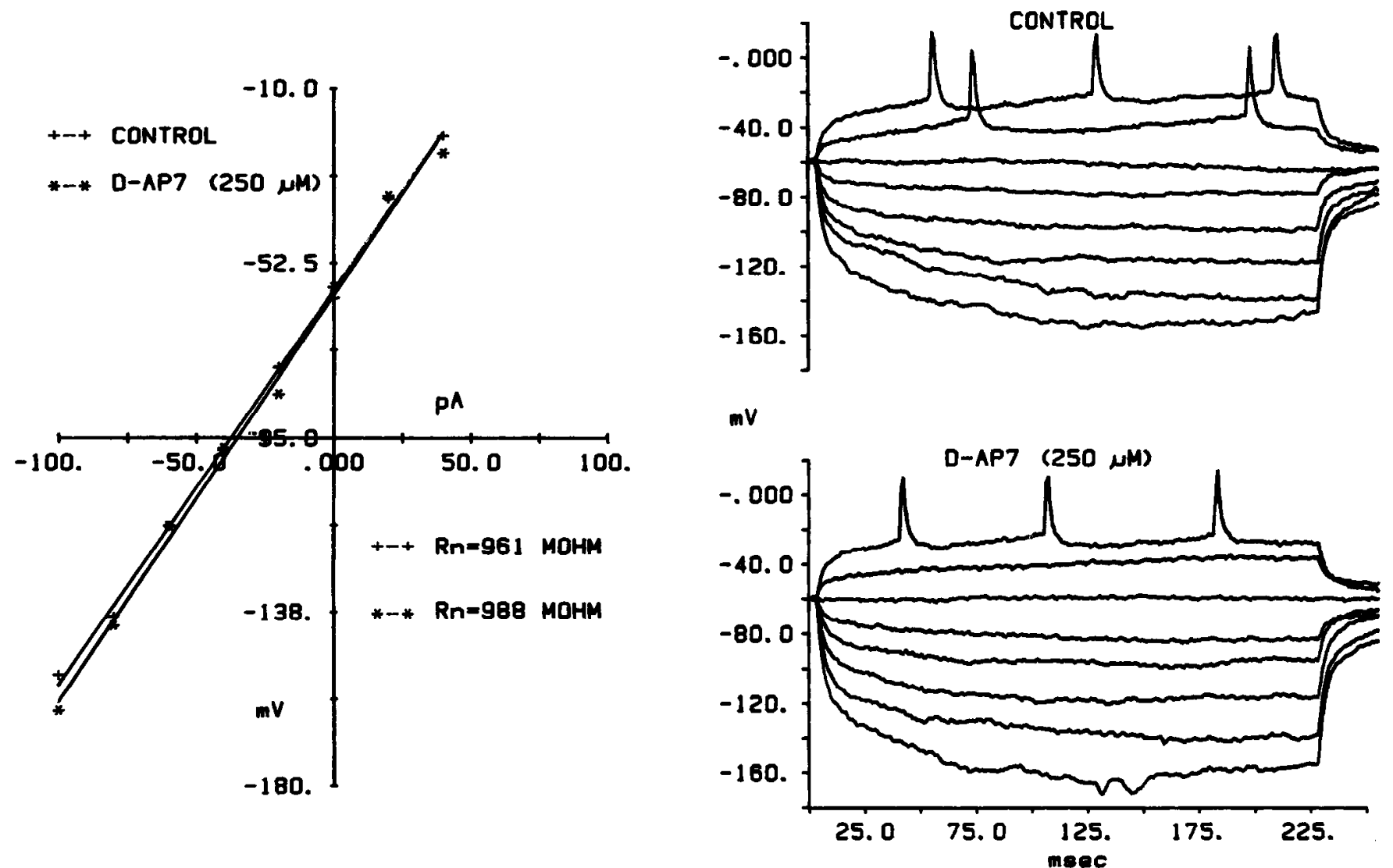

Figure 7. $I-V$ relationship measured in the presence or absence of D-AP7 $(250 \mu \mathrm{M})$ in the Off ganglion cell of the previous figure. The dark $R_{n}$ increased from 961 to $988 \mathrm{M} \Omega$ in the presence of the NMDA antagonist. Also shown are the voltage responses to the 8 current pulses (255 msec), which ranged from -100 to $+40 \mathrm{pA}$. Except for the fact that no spikes were present when a $+20 \mathrm{pA}$ current pulse was injected during the application of D-AP7, no obvious distinction between the 2 sets of curves was evident. No change in the dark resting potential was observed (-58 $\mathrm{mV}$ ) in the presence of D-AP7.

portion of light-cvoked responses in the retina. Therefore, it must be left to future studies to determine the functional importance of NMDA receptors in the vertebrate retina.

\section{References}

Bolz, J., H. Wässle, and P. Thier (1984) Pharmacological modulation of $\mathrm{ON}$ and OFF ganglion cells in the cat retina. Neuroscience 12: 875-885.

Coleman, P. A., and R. F. Miller (1987) Do NMDA receptors mediate light responses in the retina? Invest. Vis. Sci. Suppl. 28: 403.

Coleman, P. A., S. C. Massey, and R. F. Miller (1986) Kynurenic acid distinguishes kainate and quisqualate receptors in the vertebrate retina. Brain Res. 381: 172-175.

Dick, E., and R. F. Miller (1985) Extracellular $\mathrm{K}^{+}$activity changes related to electroretinogram components. J. Gen. Physiol. 85: 885909.

Forsythe, I. D., and G. L. Westbrook (1988) Slow excitatory postsynaptic currents mediated by $\mathrm{N}$-methyl-D-aspartate receptors on cultured mouse central neurons. J. Physiol. (Lond.) 396: 515-533.

Ikeda, H., and M. J. Sheardown (1983) Functional transmitters at retinal ganglion cells in the cat. Vision Res. 23: 1161-1174.

Lukasiewicz, P. D., and J. S. McReynolds (1985) Synaptic transmission at N-methyl-D-aspartate receptors in the proximal retina of the mudpuppy. J. Physiol. (Lond.) 367: 99-115.

Massey, S. C., and R. F. Miller (1985) AP-7 is a potent and specific NMDA antagonist in the rabbit retina. Invest. Vis. Sci. Suppl. 26: 117.
Massey, S. C., and R. F. Miller (1987) Excitatory amino acid receptor of rod- and cone-driven horizontal cells in the rabbit retina. J. Neurophysiol. 57: 645-659.

Mewett, K. N., D. J. Oakes, H. J. Olverman, D. A. S. Smith, and J. C. Watkins (1983) Pharmacology of the excitatory actions of sulphonic and sulphinic amino acids. In CNS Receptors-From Molecular Pharmacology to Behavior, P. Mandel and F. V. DeFeudis, eds., Raven, New York.

Miller, R. F., and R. F. Dacheux (1976) Synaptic organization and ionic basis of ON and OFF channels in the mudpuppy retina. I. Intracellular analysis of chloride-sensitive electrogenic properties of receptor, horizontal cells, bipolar cells and amacrine cells. J. Gen. Physiol. 67: 639-659.

Miller, R. F., and M. M. Slaughter (1986) Excitatory amino acid receptors of the retina: Diversity of subtypes and conductance mechanisms. Trends Neurosci. 9: 211-218.

Salt, T. E. (1986) Mediation of thalamic sensory input by both NMDA receptors and non-NMDA receptors. Nature 322: 263-265.

Slaughter, M. M., and R. F. Miller (1981) 2-Amino-4-phosphonobutyric acid: A new pharmacological tool for retinal research. Science 211: 182-185.

Slaughter, M. M., and R. F. Miller (1983) The role of excitatory amino acid transmitters in the mudpuppy retina: An analysis with kainic acid and $\mathrm{N}$-methyl aspartate. $\mathrm{J}$ : Neurosci. 3: 1701-1711.

Slaughter, M. M., and R. F. Miller (1985) Characterization of an extended glutamate receptor of the bipolar neuron in the vertebrate retina. J. Neurosci. 5: 224-233. 